\title{
Relevance of the formal red meat classification system to the South African informal livestock sector
}

\author{
Z. Soji, D. Chikwanda, A.T. Chikwanda, I.F. Jaja, B. Mushonga \& V. Muchenje \\ Department of Livestock and Pasture Science, Faculty of Science and Agriculture, University of Fort Hare, \\ Private Bag X1314, Alice, 5700, South Africa
}

(Received 31 July 2014; Accepted 7 April 2015; First published online 1 August 2015)

\begin{abstract}
Copyright resides with the authors in terms of the Creative Commons Attribution 2.5 South African Licence.
See: http://creativecommons.org/licenses/by/2.5/za

Condition of use: The user may copy, distribute, transmit and adapt the work, but must recognise the authors and the South African Journal of Animal Science.
\end{abstract}

\begin{abstract}
In 1992 the South African meat industry was deregulated and this led to the formation of the new Marketing of Agricultural Products Act, Act no. 47 of 1996. The Act made provisions for producers to sell animals to customers of their own choice at mutually agreed prices. Thus, producers in the informal sector took advantage of the free marketing system. The result was a substantial increase in the number of animals slaughtered in the informal sector. Unfortunately the requirements for animal identification are not always observed in this sector. Challenges faced by communal farmers which include the multipurpose roles of livestock, lack of slaughter facilities within reasonable distance and lack of access to market information make them less willing to sell their animals through the formal market. The formal market is characterised by meat inspection and carcass classification which scare away the communal farmers for fear of income loss through animal condemnation. The informal sector might not recognise the importance of formal carcass classification. There is need to direct research and development efforts to address marketing constraints faced by communal farmers, and to promote formal marketing of livestock for meat quality assurance and a fair return to the farmers. This review seeks to assess the relevance of formal classification of red meat carcasses to the informal sector, make recommendations on ways to ameliorate the undesirable effect of the classification system on the informal sector, and identify possible areas which need further research to develop the classification system in South Africa.
\end{abstract}

Keywords: Communal farmers, marketing system, meat industry

\#Corresponding author: vmuchenje@ufh.ac.za

\section{Introduction}

There is an increasing demand for food of animal origin in developing countries of sub-Saharan Africa and this trend is projected to continue for a long time. Consumption of meat has increased worldwide (Thornton, 2010), with highest increases being observed in the developing countries for all meat types (Thornton et al., 2009). Similar trends are being observed in South Africa (Taljaard et al., 2006; Spies, 2011). The population increase, urbanisation, changing lifestyles and consumer preferences associated with increasing disposable incomes as the middle income class increases in South Africa are expected to create market opportunities for small-scale livestock farmers (Scholtz et al., 2008; Thornton et al., 2010; Webb \& Casey, 2010).

South Africa is a net importer of mutton, lamb meat and beef as the consumption of these red meat types exceeds supply on the domestic market (DAFF, 2011; DAFF, 2012b). However, it is a net exporter of pork (DAFF, 2011). Coetzee (1998) reported that approximately $1 \%$ of the total uptake of goats is slaughtered at commercial abattoirs for distribution to urban retail outlets. This is mainly because most urbanised consumers prefer beef and mutton, while goat meat is mostly consumed during cultural ceremonies. A huge potential, therefore, exists for the small-scale sector to play a significant role in the red meat supply chain. However, for the small-scale farmers to enter the formal market which is characterised by meat inspection and carcass classification they must comply with food safety and quality standards (Mokoena, 2007). This is mainly because the efficacy of formal marketing requires that products must conform to pre-established standards. 
With increased risks of food-borne diseases, changing consumers' tastes and market requirements, strict quality control mechanisms are being put in place along the value chain from "farm to the fork" to aid in animal traceability and to ensure that high quality meat with a long shelf life reaches the consumer (Grunert, 2006; PARSAC, 2012; Govender et al., 2013). Consumers nowadays demand good quality meat which is safe and possesses health promoting attributes (Taljaard et al., 2006; Schollan et al., 2010) due to an increasing awareness of the relationship between their health and diet (Schollan et al., 2010). Attributes used to evaluate meat quality include eating quality, appearance, freshness and nutritional value (Cho et al., 2010). Eating quality is most commonly used when forming an expectation of quality before purchase and for judging quality. It is a combination of tenderness, flavour and juiciness (Cho et al., 2010). However, these characteristics are not visible to the consumer at point of purchase and are highly variable and subjective.

Variation in eating quality, particularly tenderness, is the main concern of consumers with perceived toughness resulting in unacceptable eating quality. Carcass grading schemes estimate saleable meat yield and determine the palatability or eating quality of meat by including parameters such as marbling or intramuscular fat content (Indurain et al., 2009). Marbling which is associated with juiciness, tenderness and palatability, is given high economic value and substantial premiums in beef (Indurain et al., 2009; Burrow \& Prayaga, 2004), and is often reflected in carcass grading schemes (Cho et al., 2010). Although the primary function of a carcass quality grading scheme is to segment carcasses into groups with similar palatability attributes, it does not account for differences in eating quality at the consumer level, which are related to cut type and cooking effects (Cho et al., 2010). The South African carcass classification system does not include any measure of meat quality. It has a measure of subcutaneous fat but not intramuscular fat (marbling). This shows that the South African carcass classification system is strongly inclined towards meat sellers and does not attempt to indicate the expected eating quality of the meat of the classified carcasses.

The South African classification system involves the allocation of class codes to carcasses based on the sex (signs of late castration are determined), age ( 0 teeth $=A-$ very young animal, $1-2$ teeth $=A B-$ young animal, $3-6$ teeth $=\mathrm{B}-$ old animal and more than 6 teeth $=\mathrm{C}-$ very old animal); conformation ( $1-$ very flat, 2 - flat, 3 - medium, 4 - round and 5 - very round); bruising ( 1 - slight, 2 - moderate, 3 - severe) and fat ( 0 - no fat, 1 - very lean, 2 - lean, 3 - medium, 4 - fat, 5 - slightly overfat, 6 - extremely overfat) characteristics (Agricultural Products Standard Act, 1990; SAMIC, 2006; Strydom, 2011). The classification system used in the formal sector is not viewed as favourable by communal farmers who shun the formal market as they do not appreciate the benefits of the system. Due to various challenges, communal farmers are less likely to get premium bonuses from these characteristics in the classification.

Challenges besetting communal farmers such as poor nutrition, poor management practices, inadequate knowledge, multiple roles of livestock and not keeping abreast with current technology, affect emerging livestock farmers who are unable to obtain and understand formal market information (Coetzee et al., 2005; Baloyi, 2010). As a result the system is not totally friendly to them as they are less likely to benefit from it. Consequently, they market their livestock through informal channels. In addition, the standards in the formal marketing system have been reported to be perceived negatively by the informal sector (Van de Moosdijk \& Schiferli, 2002). Despite the low levels of literacy, limitations to improved technology and communication systems which burden the informal sector, it constitutes a significant component of the agricultural economy and barriers to using the classification system should be identified and removed.

This review seeks to assess the relevance of formal classification of red meat carcasses to the informal sector in relation to the level of confidence that small-scale subsistence farmers and emerging farmers have in the current formal classification system. The review also seeks to make recommendations to relevant stakeholders on ways to ameliorate the undesirable effect of the classification system on the informal sector. Possible areas which need further research to develop the classification system in South Africa are also identified in the review.

\section{Meat production chain in South Africa}

The meat production chain in South Africa can be divided into the formal and informal sector. The formal sector comprises of commercial farmers while the informal sector is composed of small-scale subsistence farmers and emerging farmers (Scholtz et al., 2008; Spies \& Cloete, 2013). Livestock in the formal sector mainly comes from intensive farming systems for beef, mutton, pigs and poultry (Oliver, 2004). The formal market involves farmers, feedlots/auctions, abattoirs, wholesalers, retailers and consumers (DAFF, 2013a). At the processing level in the formal sector the quality control of livestock production is the responsibility of the Department of Health (Van Zyl et al., 2006). Contrary to the formal sector, livestock in the informal sector is supplied by communal farmers who are located far from the formal market. The informal market includes farmer-to-farmer or farmer-to-consumer and/or farmer-to-unregistered buyer sales. The key players in the informal food chain are communal area farmers, auctioneers, speculators and local 
traders, and the quality control in the informal sector is directly dependent on the livestock owner (Van Zyl et al., 2006).

\section{Livestock production in South Africa}

In South Africa there are about 38500 commercial farms and intensive units and an estimated two million communal and emerging farmers involved in livestock production (RMRD SA, 2012; AgriEco, 2013; Meissner et al., 2013). The country has about 13.6 million beef cattle, 24.2 million sheep, 1.13 million pigs and 6.7 million goats, with emerging and communal farmers owning $12 \%$ of the sheep (2.95 million), $63 \%$ of the goats (4.221 million), $28 \%$ of the pigs (316 400) and 41\% of the cattle (5.58 million) (RMRD SA, 2012; AgriEco 2013; DAFF, 2013a). For the $2009 / 10$ period, nearly $14.8 \%$ of the total gross value of the agricultural sector was contributed by the red meat sector. In the $2012 / 13$ period $10.1 \%$ of the total gross value (14.8 \%) was from cattle, 2.5\% from sheep (DAFF, 2010; DAFF, 2011a) and 2.15\% from pigs (DAFF, 2012a; DAFF, 2013a).

\section{Pork production}

The South African pork industry is small compared to the beef and chicken industries (Davids et al., 2014). However, it is fairly large in terms of the overall South African agricultural sector as it contributes $2.15 \%$ to the primary agricultural sector (DAFF, 2013a). Pigs are owned by 4000 commercial farmers, 19 stud breeders and about 100 smallholder farmers in South Africa (DAFF, 2011; 2012a; 2013a). The total number of sows is 125000 , of which 100000 sows belong to the commercial and 25000 to smallholder farmers (DAFF, 2011; 2012a; 2013a). The average gross value of pigs slaughtered over the past 10 years amounts to R 2.5 billion per annum. It has been further indicated that there was a steady increase in contribution of pork from 2002/3 to 2005/06 and a significant increase from 2006/7 to 2011/2012 to the gross value of agricultural production. This is mainly owing to increases in prices (DAFF, 2013a).

Prices received by farmers have positively influenced the quantity of pork produced. Consequently, in the 2011/2012 season South Africa produced 2.08 million tonnes of pork while the local consumption was only 239000 tonnes in the same year, making South Africa self-sufficient in pork production (DAFF, 2012a; DAFF 2013a). Pork production, therefore, outstrips local consumption, so that South Africa is a net pork exporter (DAFF, 2011; DAFF, 2012a; DAFF, 2013a).

\section{Beef production}

The long-term contribution of the red meat sector and beef to the total gross value of agricultural production in South Africa from $1996 / 97$ to $2008 / 2009$ stood at $13.2 \%$ and $9.4 \%$, respectively (Spies, 2011). Local demand for beef still outstrips local supply. The beef supplied by the two farming sectors meets only $85 \%$ of the beef requirements in South Africa, leaving a deficit of about $15 \%$ which is catered for through imports, making South Africa a net importer of beef (DAFF, 2011). More than $70 \%$ of all beef slaughtered in the formal sector in South Africa originates from commercial feedlots, where $67 \%$ of the feedlot animals are either crossbreeds or British and European imported breeds (53\%) (Scholtz et al., 2008). The trends of beef production have been reported to be similar to those of mutton and lamb.

\section{Mutton production}

There are about 24.2 million sheep in South Africa, which are raised by approximately 8000 commercial and 5800 communal farmers, with mutton having an average gross production value of R 3.9 billion per annum (DAFF, 2013b). The sheep breeds that are normally raised are the Dorper, which is commonly produced in arid areas and bred for mutton due to its good carcass conformation and fat, and the dual purpose breeds (mutton and wool), Damara, Meatmaster, Sulffolk and Dormer (DAFF, 2012b). The industry experiences a growing demand for mutton which cannot be matched by local production. This has resulted in the country importing mutton to meet domestic demand and consequently being a net importer of mutton. Apart from not being able to meet domestic demand, the mutton industry faces other challenges such as veterinary and traceability issues, noncompliance by some abattoirs to Health and Safety Acts, predation and theft (DAFF, 2013b).

\section{Goat production}

There are about 6.6 million goats in South Africa (De Villiers et al., 2009). Sixty-three percent of these animals are indigenous goats that are owned by communal area farmers and the remaining $27 \%$ percent are mainly Boer and Angora breeds that are reared by commercial farmers (DAFF, 2013d). Only 5.5\% of the goats are sold and slaughtered in the formal sector, while the majority of the sales are conducted on an informal basis in the communal areas, often leading to traditional slaughter for religious ceremonies (DAFF, 
2012c). Traders and speculators are the major drivers of transactions involving indigenous goats that occur in the informal sector (DAFF, 2013d).

\section{Livestock production in the informal sector}

In 1992, the South Africa meat industry was deregulated. After deregulation, new legislation including the Marketing of Agricultural Products Act (Act No. 47 of 1996) makes provisions that allow meat producers to sell their products to customers of their choice at mutually agreed prices. The legislation resulted in a surge in the informal sector leading to the sale of livestock through informal channels in South Africa. The emerging livestock farmers subsequently took advantage of the free marketing system. Van de Moosdijk \& Schieferli (2002) advocated that all livestock should conform to the regulations on animal identification for traceability purposes. Unfortunately, the informal sector has not taken heed of this recommendation due to various reasons for keeping livestock and the free marketing system which enables them to ignore the regulations.

\section{Reasons for keeping livestock in the informal sector}

Several studies have reported that income generation is the main reason for livestock keeping in the smallholder farming sector in South Africa (Musemwa et al., 2007; Mapiye et al., 2009b; Tada et al., 2012). Other reasons for livestock keeping include household animal protein supply (consumption), "live banks" for immediate cash needs, draught power provision, milk, manure and use of livestock in traditional ceremonies such as weddings, funerals, appeasement of ancestral spirits and as bride price (lobola) (Mngomezulu, 2010). Fifty-nine percent of farmers reported income generation as the main reason for keeping cattle while $26 \%$ of farmers reported that they keep cattle mainly for family consumption (meat and milk) (Musemwa et al., 2008). These are the reasons most communal farmers are less inclined to sell their livestock by means of formal marketing.

\section{Livestock marketing}

Various marketing channels are used to market livestock in South Africa, although they can be broadly categorised into informal and formal channels (Musemwa et al., 2007) as illustrated in Figures 1 and 2.

\section{Formal livestock marketing channels}

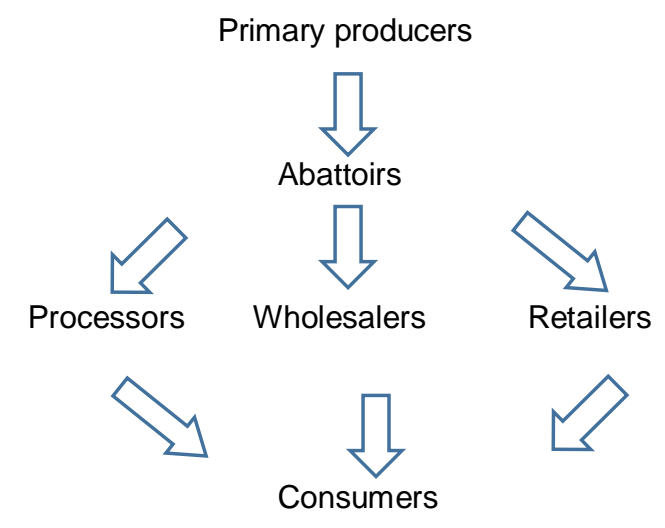

Figure 1 Formal marketing channels of livestock in South Africa.

Meat in the formal livestock sector is supplied mainly by commercial farmers. When animals reach the desired market weight, they are taken to abattoirs where quality assurance schemes comprising of carcass classification and meat inspection take place. From the abattoirs the meat is then marketed to wholesalers, retailers, processors or butcheries. The consumers can then buy from all these marketing channels.

\section{Informal livestock marketing channels}

According to Musemwa et al. (2008) and Groenewald \& Jooste (2012), smallholder farmers sell their livestock through informal markets to speculators and at auctions. The elderly and uneducated farmers prefer to sell their livestock through private sales to neighbours and relatives, while the younger farmers with at least secondary level education use private sales, auctions, abattoirs and speculators (Musemwa et al., 2008). The prices are determined on mutually based visual appraisal or live weight. The major shortcomings 
of the informal markets are seasonality of the markets, poor market information on both prices and the quality required (Groenewald \& Jooste, 2012). As a result, farmers often sell their livestock below market value, especially, to speculators, due to bad timing and a weak bargaining position (Groenewald \& Jooste, 2012).

Furthermore, the multiple roles of livestock have both positive and negative effects on the off-take rate in smallholder farming communities. On one hand, they provide an easy route with low transaction costs to the livestock producers as they do not need to transport the livestock to distant markets (Musemwa et al., 2008). On the other hand, the local buyers in the form of neighbours and relatives have low purchasing power and, therefore, offer prices below the actual value of the animals being sold, while speculators take advantage of the lack of market information to short change the farmers. When farmers are in a precarious position due to pressing cash needs, they end up being price takers and hence sell off their animals from a position of low bargaining power.

Primary producers
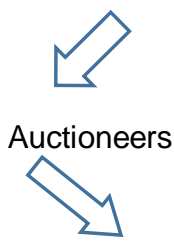
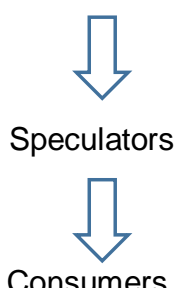

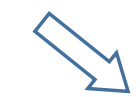

Local traders

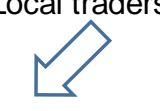

Figure 2 Informal marketing channels of livestock in South Africa.

\section{Incentives to formal classification system}

Historically, consumers have not been allowed to purchase meat directly from abattoirs and this resulted in an unwarranted increase in number of players in the meat distribution chain (Mitchell, 2014). The increase in the size of the distribution chain and the decline of face-to-face purchasing in the meat industry resulted in the need for carcass description (Mitchell, 2014). This was mainly because customers were unable to see the carcass before purchasing, thus they required a system that would describe the origin of the meat cuts in terms of carcass descriptions. The carcass description that is used in the formal meat value chain in South Africa is the carcass classification system. Strydom (2011) stated that the carcass classification system describes the quality and meat yield that benefit traders and consumers. Carcass classification is used to predict the amount of saleable meat from the carcass. As a classification system, it needs to be accurate, simple to apply, cheap and should be verifiable (Strydom, 2011).

\section{Classification at abattoir level}

The Meat Safety Act, 2000 (Act No of 40 of 2000) prohibits the slaughter of animals at any other place than approved abattoirs for the purpose of obtaining meat that is suitable for human and animal consumption. The only exception is for meat that is intended for own consumption. Approved abattoirs operate on the basis of valid registration certificates as proof that they meet certain requirements relating to structure and layout. Such abattoirs are required to have qualified meat inspectors and classifiers and are also regularly inspected to ensure that they meet hygiene requirements by removal of sick, infected and contaminated meat and animal products from the food chain. There are approximately 495 abattoirs in South Africa, grouped into five classes (A, B, C, D and E), depending on the number of animals they slaughter (DAFF, 2013b).

Abattoirs in classes A and B are highly regulated and slaughter close to $60 \%$ of the cattle. Class Aabattoirs have no limit on the number of animals, thus they can slaughter 100 slaughter units and more per day and are responsible for up to $40 \%$ of all slaughters. Class B-abattoirs slaughter up to 100 slaughter units/day, class C-abattoirs can slaughter up to 50 slaughter units/day, class D-abattoirs up to 15 slaughter units per day and class E-abattoirs up to 8 slaughter units per day (Agricultural Product standards Act, No.119 of 1990) or (classification and marking of meat). Class A- and B-abattoirs are highly controlled (regulated) and are linked to feedlots (DAFF, 2012a). The primary processing work is done at abattoirs and includes removal of the hides and quartering of the whole carcass. It is in these abattoirs that classification of carcasses should start. Butchers, hotels and supermarket then process the meat into different retail food commodities. 


\section{Techniques of carcass classification}

Meat classification is a set of descriptive terms describing features of the carcass that are useful as guidelines to those involved in the production, trading and consumption of carcasses (AHDB, 2008). It is a process which begins with meat inspection (MI) and covers a wider action involving carcass classification which is the allocation of a class code to carcasses, allowing a consumer to select a carcass according to his/her own preferences (KZN DAEA, 2005). Unlike carcass grading systems, carcass class codes do not imply that a carcass in one class is more or less desirable than a carcass in any other class (KZN DAEA, 2005).

The classification system for red meat from cattle, sheep and goats in South Africa is based on five physical characteristics comprising of age, fatness, conformation, damage and sex (RMIF, 2013). The assessment is based on visual appraisal by trained meat classifiers who are audited on a regular basis (Strydom et al., 2005; South African Meat Industry Company, 2006). As indicated by Strydom (2008), the uptake of the broad and well-intended objectives of the classification systems will depend on factors such as:

- Accuracy - where applied science will enable consistency in grouping of beef carcasses;

- Simplicity - where all segments of the industry understand how the system works;

- Ease of application - quick and easy implemented online or before the carcass is sold;

- Cost - use of simple inexpensive equipment;

- Measures against tampering - ability to verify correctness of class awarded and that the class should not be subject to change once awarded.

The following sections describe the carcass classification systems that are used in the pork, mutton, goat and beef formal sectors:

\section{Pork carcass classification}

Pig carcasses are assessed using the PORCUS classification system, as shown in Table 1, where fatness, conformation, damage and sex are the main characteristics (DOA, 2006). Fat content assessment is carried out using the Hennessey classification apparatus. Age is, however, not considered in pork classification (DOA, 2006).

Table 1 Pork classification system

\begin{tabular}{lcc}
\hline Class & Calculated \% meat of carcass & $\begin{array}{c}\text { Fat thickness measured by means of } \\
\text { an intrascope }(\mathrm{mm})\end{array}$ \\
\hline Suckling pig & $*$ & $* *$ \\
$\mathrm{P}$ & $\geq 70$ & $\leq 12$ \\
$\mathrm{O}$ & $68-69$ & $13-7$ \\
$\mathrm{R}$ & $66-7$ & $18-2$ \\
$\mathrm{C}$ & $64-5$ & $23-7$ \\
U & $62-3$ & $28-2$ \\
S & $\leq 61$ & $>32$ \\
Sausage pig & $*$ & $* *$ \\
Rough pig & $*$ & $* *$ \\
\hline
\end{tabular}

Source: Department of Agriculture, 2006.

In the pork classification system specifications, neither meat percentage (\%) nor fat thickness applies for the three classes: suckling, sausage and rough pig. Pigs that fall in the PORCUS-classes are the ones that are classified. The percentage of meat is measured between the second and third rib, $45 \mathrm{~mm}$ from the carcase midline (SAMIC, 2006).

\section{Beef, mutton and chevon classification}

Beef, mutton and chevon (goat slaughtered shortly after weaning) carcasses that are sold through the formal marketing system undergo a similar carcass classification that is based on age of the animal, fat content, conformation, bruises or damage to the carcass and sex of the animal (Agricultural Product Standards Act, No 119 of 1990). However, the Red Meat Industry Forum in South Africa has indicated that 
among these five physical characteristics the most significant characteristics during meat purchasing are age and fatness. With regard to animal sex, the major concern is the better taste of castrated male animals and most farmers castrate their animals due to higher prices they get from castrated animals (RMIF, 2013).

\section{Age, conformation, damage and sex classification}

The South African classification system classifies beef, mutton and chevon carcass maturity based on dentition alone and excludes ossification. According to Lawrence et al. (2001), dentition better describes the age of the animals across breeds and the level of nutrition compared to bone ossification. Strydom (2011) highlighted that age measured by dentition is the only component in the South African classification system that has a bearing on quality attributes of a carcass, for example tenderness. The United States Department of Agriculture (1992) has a different classification system for age that is based on muscular and skeletal development. Under the USDA (1992) system, the age of sheep is determined by assessing the joint structure on one or two front cannon bone.

Furthermore, classification simply groups carcasses into consumer preference categories which do not necessarily imply that the one is better than the other. Table 2 shows specific age, sex, damage and conformation classification for beef, mutton and chevon.

Table 2 Carcass classification of beef, mutton and chevon based on age, conformation, damage and sex

\begin{tabular}{|c|c|c|c|}
\hline Characteristic & Class & Class description & Comment \\
\hline \multirow{4}{*}{ Age } & $A$ & No permanent incisors & \multirow{4}{*}{$\begin{array}{l}\text { Carcass whose head is not available fo } \\
\text { determination of age is deemed to be in } \\
\text { class C }\end{array}$} \\
\hline & $A B$ & $\begin{array}{l}\text { At least one but not more than two } \\
\text { permanent incisor teeth }\end{array}$ & \\
\hline & $\mathrm{B}$ & $\begin{array}{l}\text { Has at least three but not more } \\
\text { than six permanent incisors }\end{array}$ & \\
\hline & $\mathrm{C}$ & $\begin{array}{l}\text { Has more than six permanent } \\
\text { incisors }\end{array}$ & \\
\hline \multirow{5}{*}{ Conformation } & 1 & Very flat & \\
\hline & 2 & Flat & \\
\hline & 3 & Medium & \\
\hline & 4 & Round & \\
\hline & 5 & Very round & \\
\hline \multirow{4}{*}{ Damage } & 0 & Undamaged & \multirow{4}{*}{$\begin{array}{l}\text { Classification considers damage in } \\
\text { relation to locality, extent and depth of } \\
\text { damage plus fat to meat to bone ratio }\end{array}$} \\
\hline & 1 & Disturbed to a slight extent & \\
\hline & 2 & Moderately disturbed & \\
\hline & 3 & Is severely disturbed & \\
\hline Sex & & & $\begin{array}{l}\text { The carcass of a ram or a bull as well } \\
\text { as of a *hamel, a *kapater or an ox } \\
\text { showing signs of late castration of the } \\
\text { A-, AB-, B- or C-age classes, are } \\
\text { identified }\end{array}$ \\
\hline
\end{tabular}

* "hamel" and "kapater" refer to castrated male sheep and goats, respectively.

\section{Fat classification}

Fat is said to be an unpopular component of meat for consumers in many countries as it is considered unhealthy (Wood et al., 2008). Despite this, fat and fatty acids whether in muscle or adipose tissue, make a significant contribution to various aspects of meat quality such as juiciness, and are fundamental to the nutritional value of meat (Wood et al., 2008). Intramuscular fat content (marbling) is considered a better parameter with regards to juiciness, tenderness and flavour and is often included in carcass grading systems. Marbling has been shown to influence consumer purchasing behaviour at the retail level, with consumers preferring lean to medium marbling rather than marbled cuts. In the case of the South African classification system, only the subcutaneous fat classification is used. As shown in Tables 3 the scoring of 
the fat class differs slightly across the two types of meat, but no scores are given for chevon in the South African classification system.

Table 3 Beef and mutton carcass classification on fatness

\begin{tabular}{llllll}
\hline Characteristic & \multirow{2}{*}{$\begin{array}{l}\text { Fatness } \\
\text { class }\end{array}$} & \multicolumn{2}{c}{ Beef } & \multicolumn{2}{c}{ Mutton } \\
\cline { 3 - 5 } Fat content & Carcass & Comment & $\begin{array}{l}\text { Carcass } \\
\text { description }\end{array}$ & Comment \\
\hline No fat & 0 & Nil & SF $<1$ & Nil & SF $<1$ \\
Very lean & 1 & SF $<1$ & $1 \leq \mathrm{SF} \leq 3.6$ & SF $<1$ & $1 \leq \mathrm{SF}<5.6$ \\
Lean & 2 & $1<\mathrm{SF} \leq 3$ & $3.6<\mathrm{SF} \leq 5.6$ & $1 \leq \mathrm{SF} \leq 4$ & $5.6 \leq \mathrm{SF} \leq 8.6$ \\
Medium & 3 & $3<\mathrm{SF} \leq 5$ & $5.6<\mathrm{SF} \leq 7.6$ & $4<\mathrm{SF} \leq 7$ & $8.6<\mathrm{SF} \leq 11.6$ \\
Fat & 4 & $5<\mathrm{SF} \leq 7$ & $7.6<\mathrm{SF} \leq 9.6$ & $7<\mathrm{SF} \leq 9$ & $11.6<\mathrm{SF} \leq 14.6$ \\
Slightly over fat & 5 & $7<\mathrm{SF} \leq 10$ & $9.6<\mathrm{SF} \leq 11.7$ & $9<\mathrm{SF} \leq 11$ & $14.6<\mathrm{SF} \leq 17.6$ \\
Excessively & 6 & $10<\mathrm{SF}$ & $11.7<\mathrm{SF}$ & $11<\mathrm{SF}$ & $17.6<\mathrm{SF}$ \\
overfat & & & & & \\
\hline
\end{tabular}

SF: subcutaneous fat thickness $(\mathrm{mm})$.

Regarding the health-related aspects of fat, meat quality evaluations have been taken further to determine the proportions of $n-3: n-6$ in the fat depot (Wood et al., 2003). n-3 fatty acids are considered healthier than n-6 fatty acids (Wood et al., 2008). Feedlot finished animals tend to contain more n- 6 than $\mathrm{n}-3$, while veld finished animals are found to have more n-3 than $n-6$ fatty acids (Wood et al., 2003). This evaluation of type of fatty acids in the fat depot does not form part of the South African classification system, so that animals both from feedlots and veld finished systems are marketed in the formal channel. Most smallholder farmers finish their animals off veld and stand to benefit from a carcass classification system that recognises the importance of the ratio of $n-3$ and $n-6$ in the meat.

\section{Significance of a formal classification system}

Consumer perception of meat quality is changing due to improved education and awareness of the relationship between health and nutrition. Consumer demands are changing as the public now find it more beneficial to improve health-related aspects through diet. Nowadays, consumers demand more information about product quality (Grunert, 2006). Credence quality is also important to consumers regarding rising concern about safety, health, convenience, locality and ethical factors (Warriss, 2000). According to Bernués et al. (2003), providing consumers with information on quality characteristics of the product enables them to evaluate quality during the process of making purchasing decisions.

A meat supplier must understand consumer demands, tangible and intangible relating to meat quality and incorporate them into the product and process characteristics in order to satisfy these demands (Bernués et al., 2003). For instance, the red meat sector, especially the beef sector, faces challenges relating to meat safety due to disease outbreaks. Meat quality is due to variability in attributes such as tenderness and meat colour as a range of different breeds are used in a wide range of production systems from veld finished to feedlot grain finished animals, which is also a challenge. Lack of consumer-oriented communication from the industry has been cited as one of the main problems of the meat sector. Meeting consumer expectations of quality and supplying them with reliable, impartial information will enable the meat industry to stay in business or to expand (Bernués et al., 2003). The consumer decision process is affected by properties of the food supplied by the industry, factors related to the consumer and the environment.

The red meat classification system in South Africa and in most countries with recognised classification systems is applied on a voluntary basis in licensed registered slaughter facilities due to deregulation of the meat industry (NDA, 2010). Although carcass classification is being applied on a voluntary basis, most retailers and wholesalers prefer classified meat as a guarantee of product safety and quality in line with consumer demands (AHDB, 2008).

In South Africa, animal carcasses are only subjected to classification on the slaughter floor with no quality indication or value attached to the classification (Strydom, 2011). This is similar to the European Grid System (Strydom, 2011). However, in the Canadian, Japanese, South Korean, USA and Australian systems there are further assessments at the chiller stage of meat quality attributes such as marbling score, meat 
colour, meat texture, fat colour, fat thickness and skeletal development (Strydom, 2011). These give an indication of the meat quality and expected eating quality to both the retailer and the consumers.

\section{Benefits of the classification system}

According to SAMIC, a classification system for red meat serves four roles, namely:

- It provides a platform for meat traders to describe their requirements when purchasing carcasses;

- It creates variety in the market with the intention of optimising consumer satisfaction;

- It enables use of price differentials;

- It is used in determining selling prices for carcasses and cuts.

A well-designed classification system is very informative and very useful to all stakeholders in the meat value chain. A classification system is designed to provide a trading platform for stakeholders in the meat value chain where they communicate using the same language (Strydom, 2011). It gives vital information through a feedback system to farmers about the type of animals they should rear to meet the requirements of consumers. It encourages producers to improve livestock performance through use of premiums for carcasses that meet the requirements of consumers and discourage supply of livestock that has a low demand or is of poor standard (Strydom, 2011). As such, it also creates a platform for consumers to make known their demands and preferences (Strydom, 2011; Mitchell, 2014).

Classification systems are tied to pricing systems for carcasses and meat and, therefore, assist producers and statutory bodies to trade efficiently and more transparently (Strydom, 2011). Carcass classification has a direct relationship to saleable meat yield (AHDB, 2008). Therefore, it can promote labelling or marking of classification information to the point of sale for branding purposes, or as quality assurance (Strydom, 2011). Hence, carcass classification systems are being developed continually to serve the purpose of facilitating trading of a very heterogeneous meat product by means of simple and universally understood language to describe the quality and yield of a carcass. This results in economic benefits for all role players in the production chain, from producer to meat trader, ultimately meeting consumer expectations and providing satisfaction.

\section{Applicability of the formal classification system to the informal livestock sector}

The quality and value of animals to be marketed are determined by physical characteristics in the classification system. However, basic procedures such as carcass classification are not practiced by the informal sector yet they are supposed to act as feedback mechanisms to the traders and farmers as well as guarantee quality to the consumers.

The FAO (2000) indicated that in the informal food chain, meat is mostly supplied by communal farmers. The quality and value of carcasses depend on the physical characteristics of the animals, though it is commonly known that animals from communal farmers might not possess the desired characteristics. This is mainly owing to some challenges that impede the implementation of the formal carcass classification in the informal sector. As a result farmers would rather opt for the informal market where considerations such as selling of animals which provide carcasses of good conformation, less bruising, lean meat, no signs of late castration and selling of young animals do not apply.

Abattoirs are, therefore, not popular marketing channels in the informal sector. Young, educated small-scale farmers were, however, found to prefer selling their livestock through abattoirs and auctions rather than through private sales and speculators (Musemwa et al., 2008), although the proportion of such farmers is low (6\%). On the other hand, most of the older small-scale or communal farmers, who are the majority of small-scale and communal farmers, have a low level of education and tend to mistrust the classification system and shun abattoirs as a result (Musemwa et al., 2008; Tada et al., 2012). It would, therefore, be difficult for them to adopt the red meat classification system if most or all of the above concerns are not addressed.

\section{Challenges that may impede implementation of the formal carcass classification in the informal sector}

The informal sector has unique attributes that might hamper the participants from appreciating the importance of formal carcass classification. In the communal setting, livestock perform multiple roles such as provision of draught power, milk, manure, use at traditional ceremonies, payment of dowry and are a form of "live bank" (Musemwa et al., 2007). The animals normally realise a terminal value for meat or are sold at mature age. Off-take is thus usually low, ranging from between $5 \%$ to $10 \%$ (Nkhori, 2004). Sales are not planned and livestock are either sold at an old age or when the need for cash arises (Mngomezulu, 2010). Unfortunately, the formal sector classifies carcasses of livestock that are sold at an old age as class C, their 
conformation tends to be flat and they attract discounted prices. Musemwa et al. (2010) reported that communal farmers shunned formal markets for fear of having their cattle condemned.

Apart from age at time of sale, the pricing system in the formal market is not favourable for indigenous animals, the majority of which have a compact body (Musemwa et al., 2010) and would not compete well on body conformation which is one of the formal classification criteria. Other constraints that limit the informal livestock producers' market include the slow maturing rate of indigenous breeds, poor nutrition, poor health management, marketing challenges, low levels of management (Spies, 2011; Spies \& Cloete, 2013), poor quality of animals produced, poor performance of herds, inconsistence production, poor pasture management, elevated feed prices and production costs (Spies \& Cloete, 2013). Coetzee et al. (2005) indicated five main marketing limitations faced by small-scale farmers in South Africa which were confirmed by Spies (2011) in the Free State Province. The limitations include poor condition of livestock, lack of marketing information, the unwillingness and inability to adopt livestock identification practices, lack of infrastructure and poor production and marketing management (Spies \& Cloete, 2013). These limitations drive informal livestock producers away from the formal market which is inclusive of the classification system. Some of the challenges impeding the implementation of the formal classification system are further discussed below.

\section{Effect of low level of management on carcass classification parameters}

The majority of communal farmers keep indigenous rather than exotic breeds (Musemwa et al., 2010). The indigenous breeds of livestock have low growth rates and are slow maturing. Popular beef breeds mostly found in cattle ranches of South Africa include the indigenous Nguni and Afrikaner and locally developed Bonsmara (Muchenje, 2007). Animals such as the Nguni do not have excellent carcass conformation and thus communal farmers are not likely to get a bonus for carcass conformation (Muchenje et al., 2008a; b). As a result farmers would rather opt for the informal sector where such a consideration is not so important. Polkinghorne et al. (2008) reported a decrease in palatability scores with increase in the level of the slow maturing $B$. indicus genes in cattle. The combined effects of slow maturing breeds and poor nutrition on small-scale subsistence and emerging farmers result in animals being marketed or slaughtered at a mature age, which are normally classified as C-class. Age plays an important role in determining meat tenderness and farmers get premium bonuses for meat from young animals (DAFF, 2011). The C-class carcasses have been reported to fetch lower prices per kilogram sold (Polkinghorne et al., 2008). Fishell et al. (1987) reported that meat from fast growing livestock was more tender compared to meat from slow maturing ones.

Cattle in the small-scale sector are sometimes used for draught purposes and are given less time during the day to forage and recover from work and thus become lean. In the case of fatness, farmers get premium bonuses for carcasses that are not too lean or not too fat. The FAO (2000) indicated that animals that are very lean or excessively fat fetch lower prices per kilogram in the formal classification system. In addition, poor management practices by communal farmers often result in the sale of animals that are poorly castrated or are castrated late, and are consequently classified as bull carcasses that are in low demand, and are poorly priced (DAFF, 2013c). Some of these animals are in poor health and at risk of being condemned at abattoirs (Dupuy et al., 2014; Stärk et al., 2014). Despite this, castrated male animals are sold for higher prices than non-castrated animals that are bruised during handling and transport which consequently results in financial losses to farmers (RMIF, 2013). These limitations, therefore, further drive communal farmers away from formal marketing to informal marketing channels.

\section{Price determination}

The informal market appears attractive to most communal and emerging farmers because animals are sold at prices which are negotiated and mutually agreed upon by both buyer and seller. In addition, the sale of the product is convenient with no added costs such as transportation or commissions (Musemwa et al., 2010). On the other hand, getting animals ready for the market in the formal sector involves preparations, which range from additional feeding or fattening and restraining of animals (Smith et al., 2004). It also encompasses transportation costs, handling of animals when loading and off-loading from vehicles (Tarrant \& Grandin, 2000), which reduce the margins realised per animal sold (Musemwa et al., 2008). These additional requirements discourage the communal or emerging farmer from participating in the formal market. Injuries of animals that may occur during transportation from the farm to the slaughter facility lead to downgrading or condemnation of carcasses (Grandin, 2000) and in worse cases the dead on arrival (DOAs) carcasses cause heavy financial loss to farmers. 


\section{Multi-purpose nature and traditional use of livestock}

Contrary to the formal sector, livestock in the informal sector are usually kept for their multi-purpose roles. They are the main suppliers for milk, meat, hides, horns, are used during religious or traditional ceremonies, to pay dowries or are kept as a form of savings (Van Zyl et al., 2006; Dovie et al., 2006; Simela et al., 2006; Musemwa et al., 2010). Animals such as cattle also provide dung which is used as manure for soil fertilisation, and provide draught power for crop cultivation and transportation of goods in communal areas (Shackleton et al., 1999; Bayer et al., 2004). The multipurpose contribution of livestock to rural livelihoods makes producers reluctant to market their animals through abattoirs (Musemwa et al., 2010). Animals intended for traditional ritual are not inspected nor slaughtered at an abattoir for purposes of classification but are rather killed in a ritual that follows the intended purpose of the ceremony. This further encourages the communal and emerging farmers to sell animals through the informal sector as livestock that are sold for traditional or religious ceremony usually attract a premium price in this sector. There is usually a high demand for animals for traditional slaughter and farmers make significant profit through this marketing channel and thus shun the formal marketing channel (Mngomezulu, 2010).

\section{Availability of marketing channels}

In terms of cattle ownership, individual households own small herds. The herd size ranges from as low as seven animals per household in the communal sector to 24 head of cattle per household in the smallscale commercial sector (Musemwa et al., 2007; Mapiye et al., 2009a), limiting their ability to sell animals for a regular income. Jooste (2001) found small-scale farmers to be in a precarious market position, which, because of their small number of livestock, cannot attract buyers to their farms. The small-scale farmers end up selling their animals through local informal marketing channels that sometimes have low purchasing power that do not recoup the appropriate value for their livestock (Nkosi \& Kirsten, 1993; Musemwa et al., 2010). Transport costs when selling few animals to abattoirs would be too high to justify their return. Therefore, farmers resort to selling to local buyers in the informal market (Mapiye et al., 2009a; Musemwa et al., 2010).

Communal farmers are further challenged by the absence of infrastructures (livestock auction sale pens, loading and offloading ramps and road networks) and lack of institutional marketing arrangements (lack of marketing agents/organisers, lack of marketing information) when they want to market their animals (Musemwa et al, 2007; Murphy, 2012). These challenges result in small-scale producers selling livestock through the informal channel at prices which are mutually agreed upon by the buyer and the seller, where key players are local traders (Van Zyl et al., 2006), and the marketing is convenient with no added transportation or commission costs. The communal farmers might, therefore, need plenty of incentive and encouragement to pursue formal markets that have a lot of challenges and classification systems that are not aligned to the multi-objective nature of their production systems. Musemwa et al. (2008) laments the lack of research and paucity of development strategies that are aimed at identifying and addressing marketing problems faced by communal farmers, and the need to find niche markets for them. Making use of marketing channels that provide best cattle prices which provide high returns remains a challenge in communal farming (Mngomezulu, 2010). There is scope, however, for small-scale farmers to use formal markets, for example Vimiso \& Muchenje (2013) observed that the majority of slaughters that were performed at a small abattoir were of cattle brought on the hoof from communal farmers within its vicinity.

\section{Conclusion and recommendations}

The livestock sector is a very important component of the economy in South Africa as over $65 \%$ of the country is suitable for extensive farming. A significant proportion of the livestock (cattle, sheep, goats and pigs) are owned by communal and small-scale emerging farmers who play a very insignificant role in the informal sector. The off-take rate from the informal sector is very low but it has a huge potential to participate in the formal meat supply chain. However, members of the informal livestock sector perceive their profitability being adversely affected by the standard abattoir meat classification system. Challenges relating to absence of infrastructure and slaughter facilities in their vicinity, problems of shortage of feed, lack of access to veterinary health care support all affect the condition of the livestock from this sector resulting in their livestock being downgraded and consequently not fetching premium prices. As an alternative, farmers resort to selling their livestock through informal markets and risk introducing contaminated or sick animals not fit for human consumption into the food chain. Consequently, consumers may buy meat which is either unsafe to their health or of poor quality from such market channels. It was, therefore, concluded that the informal sector has characteristics that hamper appreciation of the importance of formal carcass classification. Research and development efforts must address marketing constraints faced by communal farmers as well as promoting formal marketing of livestock in this sector to ensure supply of safe meat and profitability to communal livestock farmers. It is also recommended that the classification system takes into consideration 
the ranking of carcasses according to meat quality attributes for quality assurance both to farmers for the carcasses they produce and to consumers for the meat they purchase.

\section{References}

Agricultural Products Standards Act, Act No. 119 of 1990. Regulations regarding the classification and marking of meat intended for sale in the Republic of South Africa. Government Notice No. R863.

Agriculture and Horticulture Development Board (AHDB), 2008. Review of the EU carcass classification system for beef and sheep. AHDB industry consultancy. Retrieved on 13 July 2014 from www.archieve.defra.gov.uk.

AgriEco, 2013. Prospective on livestock Agriculture in South Africa. Retrieved on 20 July 2014 from www.agrieco.net.

Baloyi, J.K., 2010. Analysis of constraints facing small holder farmers in the Agribusiness value chain. A case study of farmers in Limpopo Province, MInst Agrar. thesis, University of Pretoria, South Africa.

Bayer, W., Alcock, R. \& Gilles, P., 2004. Going Backward?-Moving Forward? - Nguni cattle in communal KwaZulu-Natal. "Rural Poverty reduction through research for development and transformation". A scientific paper presented at a conference held at Agricultural and Horticultural Faculty, HumboldtUniversity zu Berlin.

Bernués, A., Olaizola, A. \& Corcoran, K., 2003. Extrinsic attributes of red meat as indicators of quality in Europe: An application for market segmentation. Food Qual. Pref. 14, 265-276.

Burrow, H.M. \& Prayaga, K.C., 2004. Correlated responses in productive and adaptive traits and temperament following selection for growth and heat resistance on tropical beef cattle. Livest. Prod. Sci. 86, 143-161.

Cho, S.H., Kim, J., Park, B.Y., Seong, P.N., Kang, G.H., Kim, J.H., Jung, S.G., Im, S.K. \& Kim, D.H., 2010. Assessment of meat quality properties and development of a palatability prediction model for Korean Hanwoo steer beef. Meat Sci. 86, 236-242.

Coetzee, R.J., 1998. Soci-economic aspects of sustainable goat production. Research and training strategies for goat production systems in SA. In: Proceedings of a workshop, 22-26 November. Eds: Webb, E.C., Cronjé, P.B. \& Donkin, E.F. pp.14-17.

Coetzee, L., Montshwe, B.D. \& Jooste, A., 2005. The marketing of livestock on communal lands in the Eastern Cape Province: Constraints, challenges and implications for the extension services. S. Afr. J. Agri. Ext. 1, 81103.

DAFF, 2010. A profile of the South African mutton market value chain. Retrieved on 30 June 2014 from www.nda.gov.za

DAFF, 2011. A profile of the South African beef market value chain. Department of Agriculture, Forestry and Fisheries, Republic of South Africa. Retrieved on 30 June 2014 from www.nda.gov.za .

DAFF, 2012a. A profile of the South African pork market value chain. Retrieved on 30 June 2014 from www.nda.gov.za .

DAFF, 2012b. A profile of the South African mutton market value chain. Retrieved on 30 June 2014 from www.nda.gov.za .

DAFF, 2012c. A profile of the South African goat market value chain. Retrieved on 30 June 2014 from www.nda.gov.za .

DAFF, 2013a. A profile of the South African pork market value chain. Retrieved on 18 July 2014 from www.nda.gov.za.

DAFF, 2013b. A profile of the South African sheep market value chain. Retrieved on 30 June 2014 from www.nda.gov.za .

DAFF, 2013c. A profile of the South African beef market value chain. Retrieved on 30 June 2014 from www.nda.gov.za .

DAFF, 2013d. A profile of the South African goat market value chain. Retrieved on 30 June 2014 from www.nda.gov.za

Davids, M.P., Jooste, A. \& Meyer, F.H. 2014. Evaluating South African pork value chain. Retrieved on 06 June 2014 from www.ifama.org.

De Villiers, J.F., Gcumisa, S.T., Gumede, S.A., Thusi, S.P., Dugmore, T.J., Cole, M., Du Toit, J.F., Vatta, A.F. \& Stevens, C., 2009. Estimation of live body weight from the heart girth measurement in KwaZulu-Natal goats. Appl. Anim. Husb. Rural Dev. 2, 1-8.

DOA, 2006. Regulations regarding the classification and marketing of meat intended for sale in the republic of South Africa. Government Notice No. R. 863.

Dovie, D.B.K., Shackleton, C.M. \& Witkowiski, E.T.F., 2006. Valuation of communal area livestock benefits, rural livelihoods and related policy issues. Land use Policy 23, 260-271.

Dupuy, C., Demont, P., Ducrot, C., Calavas, D. \& Gay, E., 2014. Factors associated with offal, partial and 
whole carcass condemnation in ten French cattle slaughterhouses. Meat Sci. 97, 262-269.

Fishell, V.K., Aberle, E.D., Judge, M.D. \& Perry, T.W., 1987. Palatability and muscle properties of beef as influenced by pre-slaughter growth rate. J. Anim. Sci. 61, 151-157.

Food and Agriculture Organisation (FAO), 2000. Red Meat Marketing. Paper No.7 on Livestock Marketing.

Govender, R., Naidoo, D. \& Buys, E.M., 2013. Managing meat safety at South African abattoirs. Int. J. Agri. Bios. Sci. Eng. 7, 3843.

Government Notices, No. R 416. Prevention of Organised Crime Act, Act No. 121 of 1998.

Government Notices, No 1106. Meat Safety Act, Act 40 of 2000.

Grandin, T., 2000. Introduction management and economic factors of handling and transport. In: Livestock Handling and Transport. Ed: Grandin, T., CABI, publishing, New York.

Groenewald, J.A. \& Jooste, A., 2012. Smallholders and livestock. In: Unlocking markets: Lessons from South Africa. Eds: Van Schalkwyk, H.D., Groenewald, J.A., Fraser, G.C.G., Obi, A. \& Van Tilburg, A., Manssholt Publication Series, Wageningen: Wageningen Academic Publishers. 10, 113-131.

Grunert, K.G., 2006. Future trends and consumer lifestyles with regard to meat consumption. Meat Sci. 74, 149-160.

Indurain, G., Carr, T., Goñi, M.V., Insausti, K. \& Beriain, M.J., 2009. The relationship of carcass measurements to carcass composition and intramascular fat in Spanish beef. Meat Sci. 82, 155-161.

Jooste, A., 2001. Economic implications of trade liberalization on the South African red meat industry, PhD thesis, University of Free State, South Africa.

KZN DAEA, 2005. The beef carcass classification system. Retrieved on 04 March 2014 from www.agriculture.kzntl.gov.

Lawrence, T.E., Whately, J.D., Montgomery, T.H. \& Perino, L.J., 2001. A comparison of USDA ossificationbased maturity system to a system based on dentition. J. Anim. Sci. 79, 1683-1690.

Mapiye, C., Chimonyo, M., Muchenje, V., Dzama, K., Marufu, M. C. \& Raats, J.G., 2007. Potential for valueaddition of Nguni cattle products in the communal areas of South Africa: A review. Afr. J. Agri. Res. 2, 488-495.

Mapiye, C., Chimonyo, M., Dzama, K., Marufu, M.C., Strydom, P.E. \& Muchenje, V., 2009a. Nutritional status, growth performance and carcass characteristics of Nguni steers supplemented with Acacia karroo leafmeal. Livest. Sci. 126, 206-214.

Mapiye, C., Chimonyo, M, Dzama, K., Raats, J.G. \& Mapekula, M., 2009b. Opportunities for improving Nguni cattle production in the smallholder farming systems of South Africa. Livest. Sci. 124, 196-204.

Marketing of Agricultural Products Act, Act No. 47 of 1996. Government Notice No. R880.

Meissner, H.H., Scholtz, M.M. \& Palmer, A.R., 2013. Sustainability of the South African livestock sector towards 2050. Part 1: Worth and impact of the sector. S. Afr. J. Anim. Sci. 43, 282-297.

Mitchell, S., 2014. Venison grading and classification. Retrieved on 13 March 2014 from www.deerfarmer.org.

Mngomezulu, S., 2010. Formal marketing of cattle by communal farmers in the Eastern Cape Province of South Africa, Can they take part? MSc thesis, Wageningen University, Netherlands.

Mokoena, M., 2007. Red meat market beckons. NAFU farmers.

Muchenje, V., 2007. Growth performance, carcass characteristics and meat quality of Nguni, Bonsmara and Angus raised on natural pasture. PhD thesis. University of Fort Hare, Alice, South Africa.

Muchenje, V., Dzama, K., Chimonyo, M., Raats, J.G. \& Strydom, P.E., 2008a. Tick susceptibility and its effect on growth performance and carcass characteristics of Nguni, Bonsmara and Angus steers raised on natural pasture. Animal 2, 298-304.

Muchenje, V., Dzama, K., Chimonyo, M., Raats, J.G. \& Strydom, P.E., 2008b. Meat quality of Nguni, Bonsmara and Angus steers raised on natural pasture in the Eastern Cape, South Africa. Meat Sci. $79,20-28$.

Murphy, S., 2012. Changing Perspectives: Small-scale farmers, markets and globalisation. (Revised edition), IIED/Hivos, London/The Hague.

Musemwa, L., Chagwiza, C., Sikuka, W., Frase, G., Chimonyo, M. \& Mzileni, N., 2007. Analysis of cattle marketing channels used by small-scale farmers in the Eastern Cape Province, South Africa. Livestock Research for Rural development. Retrieved on 22 July 2013 from www.cipav.org.

Musemwa, L., Mushunje, A., Chimonyo, M., Fraser, G., Mapiye, C. \& Muchenje, V., 2008. Nguni cattle marketing constraints and opportunities in the communal areas of South Africa: Review. Afr. J. Agr. Res. 3, 239-245.

Musemwa, I., Mushunje, A., Chimonyo, M. \& Mapiye, C., 2010. Low cattle off-take rates in communal production systems of South Africa: Causes and mitigation strategies. J. Sust. Devel. Afr. 12, 1520-1527. 
National Department of Agriculture (NDA), 2010. Agricultural Marketing strategy for the Republic of South Africa. Department of Agriculture, Forestry and Fisheries, Republic of South Africa.

Nkhori, A.P., 2004. The impact of transaction costs on the choice of cattle markets in Mahalapye district, Botswana. MSc thesis, University of Pretoria, South Africa.

Nkosi, S.A. \& Kristen, J.F., 1993. The marketing of livestock in South Africa's developing areas. A case study of the role of speculators, auctioneers, butchers and private buyers in Lebowa. Agrekon 4, 230-237.

Oliver, G.C., 2004. An analysis of the South African beef supply chain: From farm to fork. Magister Commercial thesis, Rand Afrikaans University, South Africa.

PARSAC (Provincial abattoir rating scheme award ceremony), 2012. Keynote address by honourable MEC Mrs K.C Mashego-Dlamini. Pienaarsdam ontspanningoord, Middelburg.

Polkinghorne, R., Thompson, J.M., Watson, R., Gee, A. \& Poter, M., 2008. Evolution of the Meat Standards. Australia (MSA) beef grading system. J. Anim. Sci. 80, 1351-1359.

RMIF, 2013. Classification of South African beef- A key to consumer satisfaction. Retrieved on 7 March 2014 from www.redmeatsa.co.za.

RMRD SA, 2012. Livestock production. Retrieved on 13 June 2014 from www.rmrdsa.co.za.

SAMIC, 2006. Classification of red meat. Retrieved on 12 July 2014 from www.samic.co.za.

Scholtz, M.M, Bester, J., Mamabolo, J.M. \& Ramsay, K.A., 2008. Results of the national cattle survey undertaken in South Africa with emphasis on beef. Appl. Anim. Husb. Rural Dev. 1, 1-19.

Scollan, N.D., Dhanoa, M.S., Choi, N. J., Maeng, W.J., Enser, M. \& Wood, J.D., 2010. Bio hydrogenation and digestion of long chain fatty acids in steers' fen on different sources of lipid. J. Agri. Sci. 136, 345-355.

Shackleton, C.M., Shackleton, S.E., Netshiluvhi, T.R., Mathebela, F.R. \& Phiri, C., 1999. The direct use value of goods and services attributed to cattle and goats in the Sand River Catchment, Bushbuckridge. Report No. ENV-PC-99004, CSIR, Pretoria.

Simela, L., Montshwe, B.D., Mahanjana, A.M. \& Tshuwa, M.P., 2006. The livestock production environment in the Southern African smallholder sector. New challenges for the animal science industries. SASAS 41st Congress Abstract. p. 66.

Smith, G.C., Grandin, T., Friend, T.H., Don Lay, J.R. \& Swanson, J.C., 2004. Effect of transport on meat quality and animal welfare of cattle, pigs, sheep, horses, deer and poultry. Kansas State University, USA.

Spies, D.C., 2011. Analysis and quantification of the South African red meat value chain. PhD thesis. University of Free State, Bloemfontein, South Africa.

Spies, D.C. \& Cloete, C.P., 2013. Performance and marketing options for red meat in the formal and informal value chains in the Free State Province. Conference paper presented at the $19^{\text {th }}$ International Farm Management Congress, SGGW, Warsaw, Poland.

Stärk, K.D.C., Alonso, S., Dadios, N., Dupuy, C., Ellerbroek, L., Georgiev, M. \& Lindberg, A., 2014. Strengths and weaknesses of meat inspection as a contribution to animal health and welfare surveillance. Food Control. 39, 154-162.

Strydom, P.E., 2008. Do indigenous Southern African cattle breeds have the right genetics for commercial production of quality meat? Meat Sci. 80, 86-93.

Strydom, P.E., 2011. Quality related principles of the South African beef classification system in relation to grading and classification systems of the world. S. Afr. J. Anim. Sci. 41, 177-194.

Strydom, P.E., Frylinck, L. \& Smith, M.F., 2005. Should electrical stimulation be applied when cold shortening is not a risk? Meat Sci. 70, 733-742.

Tada, O., Muchenje, V. \& Dzama, K., 2012. Monetary value, current roles, marketing options, and farmer concerns of communal Nguni cattle in the Eastern Cape Province, South Africa. Afr. J. Bus. Manage. 45, 11304-11311.

Taljaard, P.R., Jooste, A. \& Afsaha, T.A., 2006. Towards a broader understanding of South African consumer spending on meat. Agrekon 45, 214-224.

Tarrant, V. \& Grandin, T., 2000. Cattle Transport. In: Livestock handling and transport. Ed: Grandin, T., CABI Publishing, New York.

Thornton, P.K., 2010. Livestock production: Recent trends and future prospects. Phil. Trans. R. Soc. B365, 2853-2867.

Thornton, P.K., Van de Steeg, J., Notenbaert, A. \& Herero, M., 2009. The impact of climate change on livestock and livestock systems in developing countries: A review of what we know and what we need to know. Agri. Sys. 10, 113-127.

USDA, 1992. Census Agriculture. Retrieved on 15 July 2014 from uww.agricensus.usda.gov.

Van de Moosdijk, C. \& Schieferli, K., 2002. The understanding of cattle farming systems in two districts in the 
North West Province, South Africa. MSc thesis, Wageningen University, The Netherlands.

Van Zyl, E.L., McCrindle, C.M.E. \& Grace. D., 2006. Participatory risk for food safety in informal markets. International Livestock Research, University of Pretoria, South Africa.

Vimiso, P. \& Muchenje, V., 2013. A survey on the effect of transport method on bruises, $\mathrm{pH}$ and colour of meat from cattle slaughtered at a South African commercial abattoir. S. Afr. J. Anim. Sci. 43, 105-111.

Warriss, P.D., 2000. An introductory text. Meat Science. CAB International, England.

Webb, E.C. \& Casey, N.H., 2010. Physiological limits to growth and the related effects on meat quality. Livest. Sci. 130, 33-40.

Wood, J.D., Enser, M., Fisher, A.V., Nute, G.R., Whittington, F.M. \& Richardson, R.I., 2003. Effects of diets on fatty acids and meat quality. Options Meditarranéennes, Series A. 67, 133-144.

Wood, J.D., Enser, M., Fisher, A.V., Nute, G.R., Sheared, P.R., Richardson R.I., Hughes, S.I. \& Whittington, F.M., 2008. Fat deposition, fatty acid composition and meat quality: A review. Meat Sci. 78, 343-358. 